\title{
The Cellular Prion Protein PrPc Is Involved in the Proliferation of Epithelial Cells and in the Distribution of Junction-Associated Proteins
}

\author{
Etienne Morel ${ }^{1,2,39 \times a}$, Stéphane Fouquet ${ }^{1,2,39 \mathrm{db}}$, Carine Strup-Perrot ${ }^{4}$, Cathy Pichol Thievend ${ }^{1,2,3}$, \\ Constance Petit ${ }^{1,2,3}$, Damarys Loew ${ }^{5}$, Anne-Marie Faussat ${ }^{1,2,3}$, Lucile Yvernault $^{1,2,3}$, Martine Pinçon- \\ Raymond $^{1,2,3}$, Jean Chambaz ${ }^{1,2,3 a_{c}}$, Monique Rousset ${ }^{1,2,3}$, Sophie Thenet ${ }^{1,2,3 \alpha_{c}}$, Caroline Clair ${ }^{1,2,3 *}$
}

1 Centre de Recherche des Cordeliers, Université Pierre et Marie Curie-Paris 6, UMR S 872, Paris, F-75006 France, 2 INSERM, U 872 , Paris, F-75006 France, 3 Université Paris Descartes-Paris 5, UMR S 872, Paris, F-75006 France, 4 Radiosensibilité des tissus sains, UPRES EA 27.10, Institut Gustave Roussy PRI, Villejuif F-94805, France, 5 Laboratoire de Spectrométrie de Masse Protéomique, Institut Curie, Pavillon Pasteur, 75248 Paris, France

\begin{abstract}
Background: The physiological function of the ubiquitous cellular prion protein, $\operatorname{PrP}^{\mathrm{C}}$, is still under debate. It was essentially studied in nervous system, but poorly investigated in epithelial cells. We previously reported that $\operatorname{PrP}^{\mathrm{C}}$ is targeted to cell-cell junctions of polarized epithelial cells, where it interacts with c-Src.

Methodology/Findings: We show here that, in cultured human enterocytes and in intestine in vivo, the mature PrP $\mathrm{P}^{c}$ is differentially targeted either to the nucleus in dividing cells or to cell-cell contacts in polarized/differentiated cells. By proteomic analysis, we demonstrate that the junctional $\mathrm{PrP}^{\mathrm{c}}$ interacts with cytoskeleton-associated proteins, such as gamma- and beta-actin, alpha-spectrin, annexin A2, and with the desmosome-associated proteins desmoglein, plakoglobin and desmoplakin. In addition, co-immunoprecipitation experiments revealed complexes associating $\mathrm{PrP}^{\mathrm{C}}$, desmoglein and cSrc in raft domains. Through siRNA strategy, we show that $\operatorname{Pr}^{c}$ is necessary to complete the process of epithelial cell proliferation and for the sub-cellular distribution of proteins involved in cell architecture and junctions. Moreover, analysis of the architecture of the intestinal epithelium of $\operatorname{PrP}^{c}$ knock-out mice revealed a net decrease in the size of desmosomal junctions and, without change in the amount of BrdU incorporation, a shortening of the length of intestinal villi.
\end{abstract}

Conclusions/Significance: From these results, $\mathrm{PrP}^{c}$ could be considered as a new partner involved in the balance between proliferation and polarization/differentiation in epithelial cells.

Citation: Morel E, Fouquet S, Strup-Perrot C, Pichol Thievend C, Petit C, et al. (2008) The Cellular Prion Protein PrPc Is Involved in the Proliferation of Epithelial Cells and in the Distribution of Junction-Associated Proteins. PLoS ONE 3(8): e3000. doi:10.1371/journal.pone.0003000

Editor: Neil Hotchin, University of Birmingham, United Kingdom

Received April 1, 2008; Accepted July 28, 2008; Published August 20, 2008

Copyright: (C) 2008 Morel et al. This is an open-access article distributed under the terms of the Creative Commons Attribution License, which permits unrestricted use, distribution, and reproduction in any medium, provided the original author and source are credited.

Funding: E. Morel was recipient of a Ministère National de la Recherche et de la Technologie fellowship. S. Fouquet was recipient of a grant from F. Aupetit association. This work was supported in part by grants from INSERM (ATC Prion) and from Ministère de la recherche (GIS Prion).

Competing Interests: The authors have declared that no competing interests exist.

* E-mail: caroline.clair@crc.jussieu.fr

aa Current address: Department of Biochemistry, University of Geneva, 1211-GENEVA-4, Geneva, Switzerland

ab Current address: Département de Biologie Cellulaire, Inserm U567, CNRS UMR 8104, Université Paris-Descartes, Institut Cochin, 75014 Paris, France.

ac Current address: Ecole Pratique des Hautes Etudes. Laboratoire de Pharmacologie Cellulaire et Moléculaire, 75006, Paris.

9 These authors contributed equally to this work.

\section{Introduction}

The cellular prion protein $\left(\operatorname{PrP}^{\mathrm{c}}\right)$ is a ubiquitous glycoprotein anchored to the outer leaflet of the plasma membrane, in raft domains, through a glycosylphosphatidylinositol (GPI) moiety [1]. Its central role in transmissible spongiform encephalopathies has been clearly demonstrated for many years [2-4] and efforts have been made to determine its biological role apart from pathological situations. Although many cells and tissues, such as blood lymphocytes, muscle, heart, kidney, digestive tract and skin, express $\operatorname{PrP}^{\mathrm{c}}$ [5-9], most of the studies concerning its physiological function have been performed on nerve cells. In these models, it has been established that $\operatorname{PrP}^{c}$ binds copper [10] and can homodimerize [11] or interact with other proteins, among which are synapsin Ib, Grb2, Pintl, LRP/LR, and N-CAMs [12-19]. It has also been reported that $\operatorname{PrP}^{\mathrm{c}}$, via interaction with phosphorylated Fyn [20], participates in cell redox homeostasis through ROS production [21]. In addition, it has been shown that multiple biochemical changes occur in prion protein knockout mice. They include increased levels of NF- $\mathrm{KB}$ and COX-IV and decreased levels of p53 and $\mathrm{Cu}, \mathrm{Zn}$ superoxide dismutase activity, along with an increased neuronal sensitivity to oxidative stress in cultured cells isolated from these mice [22].

Much less is known about the role of $\operatorname{PrP}^{\mathrm{c}}$ in extra-neuronal tissues. In epithelial cells, $\operatorname{PrP}^{\mathrm{c}}$ was reported to be directed to basolateral membranes of MDCK and FRT epithelial cells [23]. 
We have shown that $\operatorname{PrP}^{\mathrm{c}}$ is expressed in enterocytes [24], which are highly polarized epithelial cells of the intestinal epithelium. Interestingly, we showed that, in polarized/differentiated enterocytes, $\operatorname{PrP}^{\mathrm{c}}$ is targeted to the lateral junctional complexes of adjacent cells where it interacts with Src kinase [24]. This tyrosine kinase is known targeted to cell-cell junctions where it phosphorylates substrates that induce adhesion turnover and actin remodeling [25]. Such a localization of $\operatorname{PrP}^{\mathrm{c}}$, was also observed in human keratinocytes [24] and in endothelial cells [26], opening questions about the role of $\mathrm{PrP}^{\mathrm{c}}$ in cell-cell junctions of physiological barriers.

To address this question, we focused our study on intestinal epithelium and on enterocytes, the major cell population of this epithelium. Intestinal epithelium undergoes a rapid renewal throughout life (for review see [27]). Such a process requires a continuous coordination between proliferation, differentiation and death programs, along with a remodeling of cell-matrix and cellcell contacts responsible for cell polarization. In crypts are localized stem cells and dividing cells, which migrate up to the villus where differentiation takes place. In the present work, we have analyzed whether the sub-cellular localization of $\operatorname{PrP}^{\mathrm{c}}$ varied in relation with cell proliferation, cell polarization and the state of cell-cell junctions in human intestinal epithelium in vivo and in the human Caco-2/TC7 enterocytes [28], which reproduce in culture the sequence of division and polarization/differentiation. In this enterocyte model, we characterized the partners of $\operatorname{PrP}^{c}$ in cellcell junctions. Finally, the impact of the invalidation of $\operatorname{PrP}^{\mathrm{c}}$ on the distribution of cell-cell junctions-associated proteins, the process of cell proliferation and the morphology of the intestinal epithelium was analyzed.

\section{Materials and Methods}

\section{Reagents}

Except when indicated, all chemicals were purchased from Sigma (Sigma-Aldrich, Saint Quentin Fallavier, France). Mouse 12F10 (against peptide 142-160) and SAF32 (against peptide 79-92) antihuman $\mathrm{PrP}^{\mathrm{c}}$ monoclonal antibodies were obtained from S.P.I BIO (Montigny le Bretonneux, France). Rabbit anti-human Ki67 polyclonal antibody and rat anti-mouse E-cadherin monoclonal antibody (ECCD-2) were purchased from Zymed Laboratories (San Francisco, CA). Rabbit anti-human Src (sc-18), and goat antihuman poly (ADP-ribose) polymerase (PARP) antibodies were purchased from Santa Cruz Biotechnology (Santa Cruz, CA). Mouse anti-human calnexin, desmoglein, plakoglobin and annexin A2 monoclonal antibodies were purchased from BD Biosciences (Erembodegem, Belgium). Rabbit anti-human $\operatorname{PrP}^{\mathrm{c}}$ (Ab 703), antipan desmoglein, anti-desmoplakin, anti phospho-S10-Histone H3 (Ab5176) polyclonal antibodies and rat anti-BrdU monoclonal antibody were purchased from Abcam (Cambridge, UK). Secondary CY2-, CY3- and CY5-labelled antibodies were purchased from Jackson Immuno-Research (West Grove, PA). F-actin was labelled with phalloidin-FITC. Endoglycosidase F was purchased from VWR (Fontenay sous bois, France). The biotinylated pro-aerolysin bacterial toxin [29] was a kind gift from Gisou van der Goot (Ecole Polytechnique de Lausanne, CH-1015 Lausanne, Switzerland).

\section{Cell culture}

All culture media were purchased from Gibco, Invitrogen Life Technologies (Cergy Pontoise, France). Caco-2/TC7 cells [28] were cultured with high glucose DMEM (Dulbecco's modified Eagle's medium) Glutamax I supplemented with 20\% heat inactivated $\left(56^{\circ} \mathrm{C}, 30 \mathrm{~min}\right)$ fetal calf serum (AbCys, Paris, France), $1 \%$ non-essential amino acids, penicillin $(100 \mathrm{IU} / \mathrm{ml})$ and streptomycin $(10 \mu \mathrm{g} / \mathrm{ml})$ in a $10 \% \mathrm{CO}_{2} /$ air atmosphere. The medium was changed every day. Depending on experiments, cells were plated on $1 \mu \mathrm{m}$ pore size microporous PET filters (Falcon, BD Biosciences, Franklin lakes, NJ), or in plastic flasks (Falcon) or on glass lamellae (Polylabo, Strasbourg, France).

\section{Cells treatments}

Cycloheximide treatment. When indicated, the cells were treated with cycloheximide $(10 \mu \mathrm{M}$ final concentration).

siRNA transfection. siRNA corresponding to the human Prnp gene from codon 399 to 417 was synthesized by MWG Biotech (Ebersberg, Germany). The specific human siRNA sequence used was: 5'-GGG-GAG-UAA-GCG-AAA-AAC-CTT-3' (sense). Cells were seeded at $5000 \mathrm{cell} / \mathrm{cm}^{2}$ on plastic or glass lamellae. siRNAs were mixed with Oligofectamine reagent (Invitrogen Life Technologies) for $15 \mathrm{~min}$ and Opti-MEM medium without serum was added according to the manufacturer's instructions. The final concentration of siRNA was $400 \mathrm{nM}$. After incubation for 6 hours at $37^{\circ} \mathrm{C}$, Opti-MEM supplemented with $60 \%$ fetal calf serum was added to reach a final $20 \%$ serum concentration. A mouse $\operatorname{PrP}^{\mathrm{c}}$ siRNA sequence (5'-GCG-CAG-CAA-ACG-AAA-AAC-CTT-3'), inefficient on human $\operatorname{PrP}^{c} \mathrm{RNA}$, and a scramble siRNA (5'-CGGAGA-AGU-AAA-GCG-AAC-CTT-3') were used as controls along with cells incubated with Oligofectamine reagent only. After $24 \mathrm{~h}$, the medium was changed for the standard medium and the cells from all conditions were maintained in culture for the indicated times, the medium being changed every day.

\section{GFP-PrPc plasmid construct and cell transfection}

pEGFP-mouse $\operatorname{PrP}^{c}$ plasmid [30] was obtained from MA Prado. GFP-PrP $\mathrm{P}^{\mathrm{c}}$ was originally under the control of $\mathrm{CMV}$ promoter in this plasmid. To allow the expression of GFP-PrP ${ }^{c}$ in differentiated cells, the corresponding sequence was subcloned into pGL2basic vector (Promega France) under the control of SV40 promoter. Caco-2/TC7 cells were transfected on day 2 with oligofectamine (Invitrogen, France) according to the manufacturer's instructions. After selection with G418 (Gibco BRL, France), transformed cells were allowed to expand prior to sorting, on the basis of GFP fluorescence, in an ALTRA cell sorter (Beckman Coulter, France).

\section{Immunofluorescence analysis}

Cells were washed twice with PBS containing $1 \mathrm{mM} \mathrm{CaCl}_{2}$ and $0.5 \mathrm{mM} \mathrm{MgCl}_{2}$, and fixed for $30 \mathrm{~min}$ with $4 \%$ paraformaldehyde (wt/vol) in PBS at $4^{\circ} \mathrm{C}$. After an extensive washing in $150 \mathrm{mM}$ glycine in PBS (PBS-glycine), the cells were permeabilized by incubation for $30 \mathrm{~min}$ in $0.1 \%$ Triton X-100 in PBS and washed in PBS-glycine followed by PBS plus 1\% BSA. Cells were incubated for $60 \mathrm{~min}$ at room temperature with primary antibodies in PBS supplemented with $1 \%$ BSA, washed with PBS and stained with secondary antibodies in PBS with $1 \%$ BSA for $60 \mathrm{~min}$ at room temperature in the dark. After extensive washing in PBS, cells were mounted in Fluoprep (BioMérieux, Marcy l'Etoile, France), and examined by epifluorescence microscopy (Axiophot microscope connected to Axiocam camera using Axiovision 4.5 software; Carl Zeiss). Confocal microscopy (LSM 510 microscope; Carl Zeiss, Jena, Germany) was used for the observation of cells cultured on microporous filters, which are strongly autofluorescent and generate excessive background in epifluorescence. $\mathrm{X}-\mathrm{Z}$ planes resulted from $0.1 \mu \mathrm{m}$ stacks.

\section{Tissue analysis}

$\operatorname{PrP}^{\mathrm{C}}$ knock out mice [2] backcrossed on C57Bl6 and their wild type C57Bl6 counterparts were purchased from CDTA (Orléans, 
France). After removal of intestine in wild type or $\operatorname{PrP}^{\mathrm{c}}$ knock out mice, $2 \mathrm{~cm}$ segments of duodenum and jejunum were cut, gently flushed with PBS and opened longitudinally. Rolled segments were frozen in cryo-embedding media (OCT) and stored at $-80^{\circ} \mathrm{C}$ until cryostat sectioning $(10-20 \mu \mathrm{m})$. Sections were applied onto gelatine-coated glass slides, fixed in paraformaldehyde solution (4\%), permeabilized with Triton before DAPI staining and then mounted in fluoprep solution.

Mitotic crypt cells were labeled with an anti-phosphoS10Histone H3, using the same protocol as for cell immuno-labeling. To label proliferating intestinal crypt cells in S-phase, $\mathrm{PrP}^{\mathrm{c}}$ knock out and wild-type $\mathrm{C} 57 \mathrm{Bl} 6$ mice were given an intraperitoneal injection of 5-bromo-2'-deoxyuridine (BrdU; Sigma; $120 \mathrm{mg} / \mathrm{kg}$ body weight) $90 \mathrm{~min}$ before sacrifice. Paraffin sections of alcoholformalin-acetic acid (AFA)-fixed jejunum were incubated for $30 \mathrm{~min}$ in $2.5 \mathrm{~N} \mathrm{HCl}$ before processing for immunofluorescent labeling with anti-BrdU antibody.

Sections from paraffin-embedded human jejunum were sequentially treated with xylene $(2 \times 5 \mathrm{~min}), 100 \% \mathrm{EtOH}(2 \times 5 \mathrm{~min}), 95 \%$ $\mathrm{EtOH}(1 \times 5 \mathrm{~min})$ and then rinsed with water. Antigens retrieval was performed by boiling slides in $10 \mathrm{mM}$ citrate buffer $(\mathrm{pH}$ 6) for 10 min. After washes in PBS, sections were fixed and then the same protocol as described above for immunofluorescence was used.

\section{Immunoelectron microscopy}

Caco-2/TC7 cells, grown on Thermanox coverslips (Agar scientific), were fixed with acetone. After incubation with $12 \mathrm{~F} 10$ monoclonal antibody, gold (1 nm particles)-labelled goat anti mouse IgG (Amersham Biosciences) were used as secondary antibodies and the resulting signal was enhanced by the Intense TM M silver enhancement kit (Amersham Biosciences). After alcohol-graded dehydratation, sections were embedded in Epon and ultrathin sections were analyzed (Jeol 100 CX II). For desmosomal structure analyses, intestine was flushed with cold $0.1 \mathrm{M}$ Phosphate buffer ( $\mathrm{pH} 7.4$ ), ligatured and filled with cold $2.5 \%$ glutaraldhehyde $/ 0.5 \%$ tannic acid in $0.1 \mathrm{M}$ cacodylate buffer at $\mathrm{pH} 7.4$ for $2 \mathrm{H}$. Fine samples of intestine were cut and fixed by $0.6 \%$ glutaraldhehyde $/ 0.5 \%$ tannic, which stains and preserve the ultrastructure of phospholipids [31] in the same buffer overnight at $4^{\circ} \mathrm{C}$. Postfixation was carried out in $2 \%$ osmic acid in $0.1 \mathrm{M}$ Phosphate buffer for $1 \mathrm{~h}$ at $4^{\circ} \mathrm{C}$. Samples were then dehydrated in graded alcohol and embedded in Epon resin (Poly/Bed 812, Polysciences Inc.Warrington, PA). Ultrathin sections of around $65 \mathrm{~nm}$ were counterstained with uranyl acetate $\left(30 \mathrm{~min}, 40^{\circ} \mathrm{C}\right)$ and lead citrate $\left(10 \mathrm{~min}, 25^{\circ} \mathrm{C}\right)$ using an LKB 2168 ultrostainer. Observations were made using a JEOL CX100 equipped with a Gatan Digital camera (3.11.0) and the migrographs were processed with Gatan software.

\section{Sub-cellular fractionation}

Preparation of detergent-insoluble membranes on sucrose gradient. Caco-2/TC7 cells were homogenized on ice for $30 \mathrm{~min}$ in $2 \mathrm{ml}$ of $10 \mathrm{mM}$ Tris- $\mathrm{HCl} \mathrm{pH} 8,150 \mathrm{mM} \mathrm{NaCl}$ buffer (TN) containing 1\% Triton X100 or in $2 \mathrm{ml}$ of $20 \mathrm{mM}$ Tris-HCl $\mathrm{pH} 7.8,250 \mathrm{mM}$ sucrose, $1 \mathrm{mM} \mathrm{CaCl}{ }_{2}$ and $1 \mathrm{mM}$ $\mathrm{MgCl}_{2}$ without detergent [32]. Anti-protease cocktail and antiphosphatases (orthovanadate and beta-glycerophosphate) were added in both conditions. The cell homogenate was then adjusted to $40 \%$ sucrose by addition of $2 \mathrm{ml}$ sucrose $(80 \%$ in $\mathrm{TN})$. The resulting $4 \mathrm{ml}$ were covered with $4 \mathrm{ml}$ of $30 \%$ sucrose and $4 \mathrm{ml}$ of $5 \%$ sucrose and centrifuged for $16 \mathrm{~h}\left(39,000 \mathrm{rpm}, 4^{\circ} \mathrm{C}\right)$ in a $\mathrm{SW}$ 41 rotor (Beckman Instruments, Gagny, France). Sequential $1 \mathrm{ml}$ fractions were then collected from the top of the tube and the turbid fraction containing the floating detergent-insoluble membranes (fraction 4) was adjusted to $11 \mathrm{ml}$ in TN buffer and centrifuged in a SW-41 rotor $(35000 \mathrm{rpm}, 1 \mathrm{~h})$. The pellet was dissolved in TN buffer containing 1\% NP40, anti-proteases and anti-phosphatases and stored at $-80^{\circ} \mathrm{C}$ until immunoprecipitations.

Nuclei and crude membrane preparations. Proliferating or polarized/differentiated Caco-2/TC7 cells were washed twice in $10 \mathrm{mM}$ Tris-HCL pH 7.5 containing $20 \mathrm{mM} \mathrm{KCl}, 2 \mathrm{mM}$ $\mathrm{CaCl} 2,2 \mathrm{mM} \mathrm{MgCl} 2$ and $0.2 \mathrm{mM}$ spermidine (TKCM buffer) and scrapped in TKCM containing $1 \%$ Triton X-100, $1 \mathrm{mM}$ phenylmethylsulfonylfluoride (PMSF), anti-proteases and antiphosphatases. Nuclei were pelleted by centrifugation at $1000 \mathrm{~g}$ for $10 \mathrm{~min}$ at $4{ }^{\circ} \mathrm{C}$ and supernatants corresponding to cytosolic and membrane proteins were stored at $-80^{\circ} \mathrm{C}$ until analysis. The pellets were washed in TKCM buffer and nuclear proteins were extracted with $2 \mathrm{M} \mathrm{NaCl}$ in TKGM buffer for $1 \mathrm{~h}$ at $4^{\circ} \mathrm{C}$. Excess $\mathrm{NaCl}$ was removed by overnight dialysis against PBS at $4^{\circ} \mathrm{C}$.

\section{Immunoprecipitation and immunoblotting analyses}

The raft fractions were immunoprecipitated with rabbit anti$\operatorname{PrP}^{\mathrm{c}}$ (Ab 703) polyclonal antibodies, or non-specific rabbit immunoglobulins or anti-pan desmoglein antibodies coupled to protein A-sepharose 4B (Amersham Biosciences, Orsay, France). For SDS-PAGE, samples were boiled for $10 \mathrm{~min}$ in Laemmli buffer $(2.5 \%$ SDS final concentration) and fractionated under reducing conditions in polyacrylamide gel. Proteins were transferred onto nitrocellulose membranes (Bio-Rad), blocked 2h with $5 \%$ non-fat dried milk in TBS $/ 0.1 \%$ Tween 20 (TBST). After two washes in TBST, membranes were incubated (1h at room temperature) with specific antibodies. After three washes in TBST, the membranes were incubated ( $1 \mathrm{~h}$ at room temperature) with peroxidase-labelled (HRP) secondary antibodies (Amersham Biosciences) in TBST. After three washes in TBST, bound antibodies were detected by chemiluminescent method (ECL, Amersham Biosciences). The quantitative analyses were performed with a high performance calibrated imaging densitometer (Bio-Rad GS-800) using PD Quest and Image Quant 5.2 softwares.

GPI anchor detection. After SDS-PAGE of immunoprecipitated materials and transfer onto nitrocellulose, membranes were incubated two hours in a binding buffer $(50 \mathrm{mM} \mathrm{NaH} 2 \mathrm{PO} 4 / 0.3 \%$ Tween 20) before addition of biotinylated pro-aerolysin bacterial toxin. Biotinylated proteins were detected by blotting with HRPconjugated streptavidin

Endo F treatment. Nuclear proteins and rafts extracts were treated with Endoglycosidase $\mathrm{F}$ (10 units/50 $\mu \mathrm{g}$ proteins) in $40 \mathrm{mM}$ sodium phosphate buffer, $\mathrm{pH} 7.5$ containing $0.4 \%$ SDS, $20 \mathrm{mM}$ DTT and $0.8 \% \mathrm{NP} 40$ for 16 hours at $37^{\circ} \mathrm{C}$ before immunoblot analysis.

\section{MS analysis}

SDS/PAGE separation and protein digestion. Raft fractions were immunoprecipitated with anti $\operatorname{PrP}^{\mathrm{c}}$ antibodies and separated on 4-12\% SDS/polyacrylamide gels. After staining with colloidal Commassie blue (G250, Bio-Rad), the visualized bands were cut into slices of $1 \mathrm{~mm}$. Gel slices were then reduced, alkylated and subjected to digestion with trypsin (Roche Diagnostics) as already described [33]. Extracted peptides were dried and solubilized in solvent A (95/5 water/acetonitrile in $0.1 \%$ (w/v) formic acid). The total digestion product of a gel slice was used per liquid chromatography-tandem MS (MS/MS) analysis.

Liquid chromatography-MS/MS analysis. The extracted peptides were concentrated and separated on a LC-Packing system (Dionex S.A.) coupled to the nano-electrospray II ionisation 
interface of a QSTAR Pulsar i (Applied Biosystems) using a PicoTip $(10 \mu \mathrm{m}$ i.d., New Objectives, Woburn, MA). The MS/ MS data was searched twice by using MASCOT (Matrix Science, London) and PHENYX (Geneva Bioinformatics S.A.) softwares on internal servers, first without taxonomic restriction to reveal the presence of proteins of interest and mammalian contaminants, then again the National Center for Biotechnology Information Human database (National Library of Medicine, Bethesda). All data are manually verified in order to minimise the errors in protein identification and/or characterization.

\section{Statistical analysis}

Statistical analyses were performed using student's $t$ test.

\section{Results}

The cellular prion protein is localized in the nucleus in dividing cells and in cell-cell junctions in polarized epithelial cells

We analyzed, by immunofluorescence and immunoelectron microscopy, the distribution of $\operatorname{PrP}^{\mathrm{c}}$ or of $\mathrm{GFP}_{-} \mathrm{PrP}^{\mathrm{c}}$ in exponentially growing or polarized Caco-2/TC7 enterocytes. Representative images of $\operatorname{PrP}^{c}$, E-cadherin and DAPI labeling of the nuclei in exponentially growing Caco-2/TC7 cells (day 3) are shown in Figure 1A. When cells have not yet established welldefined adherens junctions, as shown by the poor expression of Ecadherin at cell-cell contacts (left panel), $\operatorname{PrP}^{\mathrm{c}}$ was mainly detected intracellularly. Interestingly, this staining co-localized with DAPI labeling, in the nucleus (middle panel). Immunodetected $\operatorname{PrP}^{\mathrm{c}}$ appeared as dots that were distributed around the nucleolus (right panel). This localization was confirmed by immunoelectron microscopy where the $\operatorname{PrP}^{c}$ signal appeared accumulated in the nucleus (Fig. 1B, N) and systematically excluded from the nucleolus (Fig. 1B, *). The nuclear localization of the transfected mouse GFP-PrP ${ }^{\mathrm{C}}$ at this stage of the culture further strengthened the results obtained for the endogenous protein (Fig. 1C).

In confluent and polarized Caco-2/TC7 cells (day 10), when Ecadherin-dependent junctions were established, $\operatorname{PrP}^{\mathrm{C}}$ was detected at the lateral membrane, and did not co-localize with DAPI in 90$95 \%$ of the cells (Fig. 1D). GFP-PrP ${ }^{c}$ was also found targeted to the lateral membranes of polarized cells (Fig. 1E). This $\operatorname{PrP}^{\mathrm{c}}$ localization was previously revealed by immunoelectron microscopy [24]. As cells were not synchronized, $\operatorname{PrP}^{\mathrm{C}}$ was found in the nucleus in the few dividing cells $(5-10 \%)$ that were still present within the confluent cell layer. In all conditions, a significant proportion of trafficking $\operatorname{PrP}^{\mathrm{c}}$, which corresponded to approximately $30-40 \%$ of the total protein, was also observed in the cytoplasm.

\section{The cellular prion protein is differently localized in proliferative and differentiated compartments of human intestinal epithelium \\ The sub-cellular localization of $\operatorname{PrP}^{\mathrm{c}}$ was analyzed in human} intestinal epithelium and compared in crypts and villi, which correspond to the proliferative and differentiated compartments, respectively. In crypts, $\mathrm{PrP}^{\mathrm{c}}$ was found to co-localize with $\mathrm{Ki}-67$, a nuclear marker of dividing cells (Fig. 2A). By contrast, in the cryptvillus transition compartment (Fig. 2B) and in villi (Fig. 2C), i.e. as soon as the process of cell division is stopped and the differentiation takes place, the nuclei, visualized by DAPI, were found devoid of $\mathrm{Ki} 67$ and of $\mathrm{PrP}^{\mathrm{c}}$, which was visualized in the cytoplasm and in the lateral membranes of adjacent cells.
Nuclear and junctional $\mathrm{PrP}^{\mathrm{C}}$ isoforms exhibit similar posttranslational modifications but differ in their stability

The differential sub-cellular localization of $\mathrm{PrP}^{\mathrm{c}}$ could result from different molecular properties of the protein. Thus, we first compared the stability of $\operatorname{PrP}^{\mathrm{c}}$ when localized in the nucleus or in the lateral membranes. The amount of $\operatorname{PrP}^{\mathrm{c}}$ was determined by western blot, in nuclear extracts from proliferative cells (day 3) and membrane $\mathrm{PrP}^{\mathrm{c}}$-containing raft domains from differentiated Caco2/TC7 cells (day 10), at different times after inhibiting translation by cycloheximide. Results reported in Figure $3 \mathrm{~A}$ show that $\operatorname{PrP}^{\mathrm{c}}$ is much more stable when localized in the nucleus, where degradation could not be observed over a 3 hour period, than at the membrane, where $50 \%$ of the protein were degraded at 30 min.

$\operatorname{PrP}^{\mathrm{c}}$ is submitted to post-translational modifications such as $\mathrm{N}$ linked glycosylation and addition of a GPI anchor. Endo F treatment of nuclear or raft extracts resulted in an equivalent shift of $\operatorname{PrP}^{c}$ bands, demonstrating that nuclear and raft $\operatorname{PrP}^{c}$ are similarly N-glycosylated (Fig. 3B). Analysis of the presence of a GPI anchor was performed on $\operatorname{PrP}^{\mathrm{c}}$ immunoprecipitated by the specific polyclonal rabbit antibodies Ab 703, using the biotinylated pro-aerolysin bacterial toxin, which recognizes GPI anchors [29]. A specific band corresponding to the presence of a GPI anchor on $\operatorname{PrP}^{\mathrm{c}}$ was detected in both nuclear and raft extracts (Fig. 3C, middle panel), at the same molecular weight as the $\operatorname{PrP}^{\mathrm{c}}$ signal (Fig. 3C upper panel), i.e. at $30 \mathrm{kDa}$. The absence of contamination of the nuclear and raft extracts with proteins derived from the other compartment was verified. Calnexin protein, which is known to be regularly buoyed with rafts [34] and the poly-(ADP-ribose) polymerase (PARP) protein that is exclusively expressed in the nucleus were used as markers of the respective compartments (Fig. 3C, lower panels).

\section{Junctional $\mathrm{PrP}^{\mathrm{C}}$ is part of a complex involving desmosome-associated proteins and c-Src, and interacts with the structural proteins actin and annexin A2}

A proteomic analysis was undertaken to determine the partners of $\mathrm{PrP}^{\mathrm{c}}$ in the junctional domains of enterocytes. Results presented in table 1 showed that the membrane $\operatorname{PrP}^{c}$ interacts with five desmosome-associated proteins, among which desmoglein, plakoglobin and desmoplakin, and with gamma- and beta-actin and annexin A2, a structural protein that is known to participate in the regulation of actin cytoskeleton dynamics in junctions of epithelial cells [35]. The interaction with the desmosomal proteins and with annexin A2 was corroborated by western blots after purification of rafts in the presence of detergent and immunoprecipitation of $\operatorname{PrP}^{\mathrm{c}}$ by the specific rabbit polyclonal antibodies Ab 703 (Fig. 4A). Same results were obtained with rafts purified, after sucrose gradients, from cell extracts prepared without detergent (not shown). The absence of interaction between E-cadherin and $\operatorname{PrP}^{\mathrm{c}}$ [24] was confirmed, since E-cadherin was recovered exclusively in the immunoprecipitation supernatant (Fig. 4B). Interestingly, besides the already reported interaction of $\mathrm{c}-\mathrm{Src}$ with the junctional $\operatorname{PrP}^{\mathrm{c}}$ [24], the immunoprecipitation of raft fraction with the antitransmembrane protein desmoglein antibody revealed a complex including c-Src, desmoglein, and $\operatorname{PrP}^{\mathrm{c}}$ (Fig. 4C), while, as expected, desmoglein and E-cadherin did not interact.

$\operatorname{PrP}^{c}$ invalidation impairs the sub-cellular localization of junction-associated proteins and desmosome structure

Based on its interaction with desmosomal proteins, studies were undertaken to determine whether $\operatorname{PrP}^{\mathrm{c}}$ could be involved in the organization of cell-cell junctions. Enterocytes were thus treated 


\section{day 3}

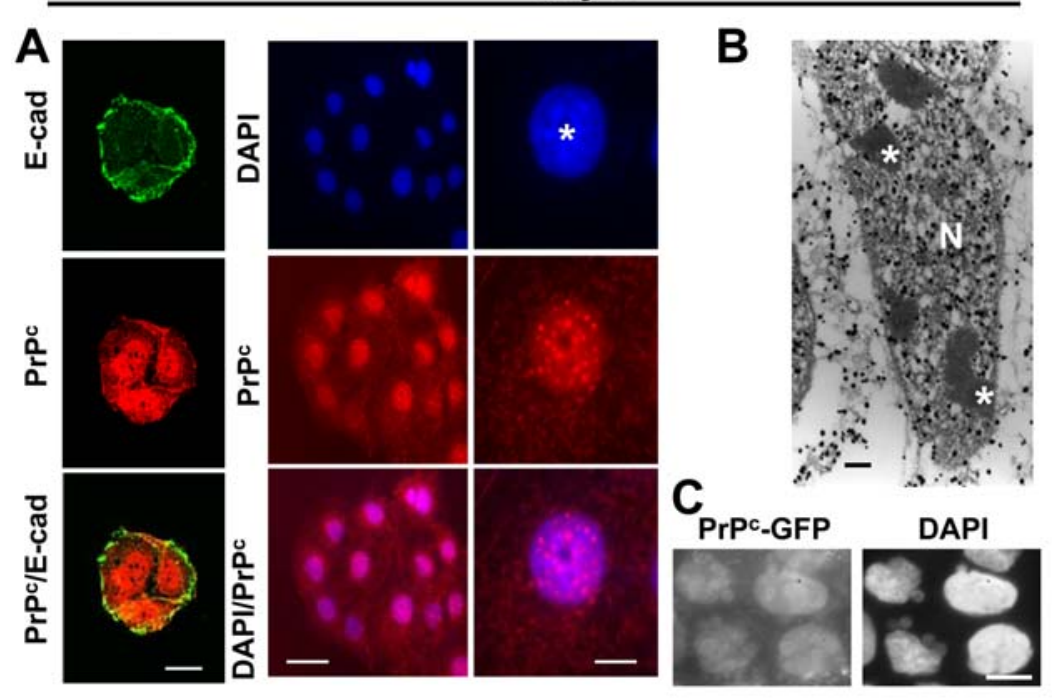

day 10
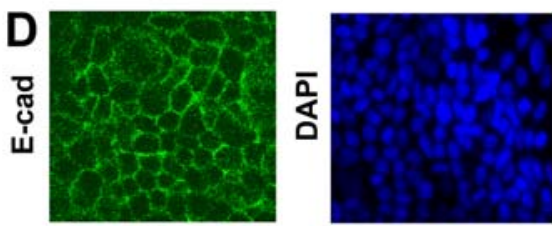

E
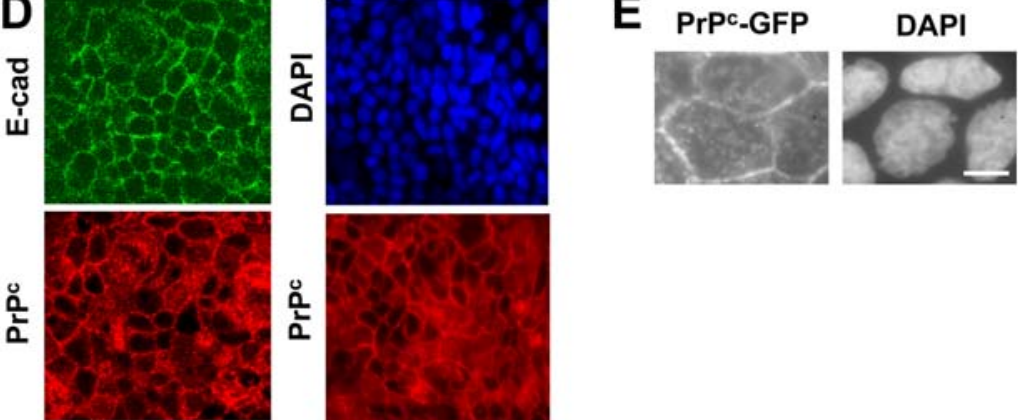

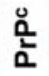
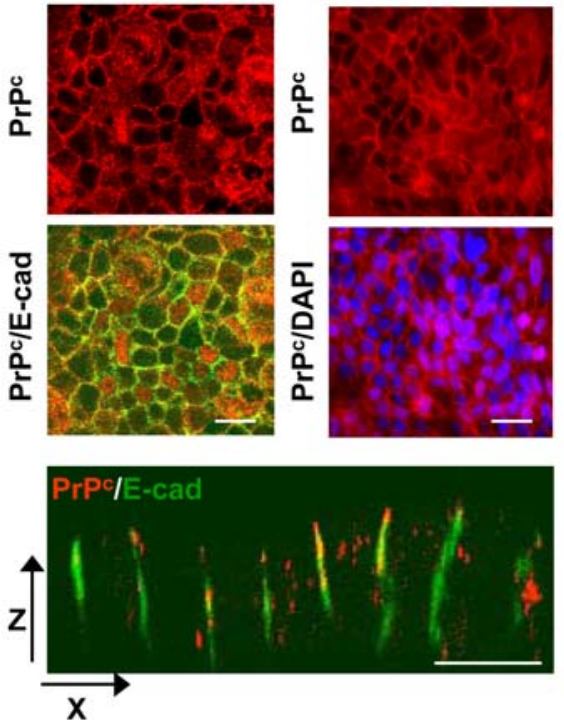

Figure 1. Expression and localization of $\mathrm{PrP}^{\mathrm{c}}$ in proliferating or differentiated/polarized Caco-2/TC7 cells. Immunofluorescence labeling of $\operatorname{PrP}^{c}$ (red, 12F10 antibody) and E-cadherin (green) was performed after 3 (A, left panel) or 10 (D, left panel) days in culture. Nuclei were stained with DAPI (A, middle and right panels, D, right panel). Right panels in A represent an enlargement of a typical nuclear labeling of one cell $(*$, nucleolus). Note that left panels correspond to a cluster of three cells and middle panels to a cluster of 13 cells. (B): Immunoelectron microscopy of $\mathrm{PrP}^{\mathrm{C}}$ was performed on day 3. (N, nucleus; *, nucleolus). (C, E): Sub-cellular localisation of GFP-PrPc was analyzed on day 3 or 10 and compared with DAPI staining (right panels). Note the absence of $\operatorname{PrP}^{c}$ and of E-cadherin, used as a marker of the junctional state, at the cell-cell contacts of proliferative cells $(A)$ and their presence in the lateral membranes of polarized/differentiated cells as shown in XY (upper panels D) and XZ (lower panel D) planes. Bars: (A) $10 \mu \mathrm{m}$ for left panels, $20 \mu \mathrm{m}$ for middle panels and $4 \mu \mathrm{m}$ for right panels, (B) $1 \mu \mathrm{m}$, (C and E) $10 \mu \mathrm{m}$ and (D) $20 \mu \mathrm{m}$. doi:10.1371/journal.pone.0003000.g001

with human $\operatorname{PrP}^{\mathrm{c}}$-siRNA, before the onset of cell polarity and the formation of cell-cell junctions. A kinetic analysis of $\operatorname{PrP}^{\mathrm{c}}$ levels in transfected cells, by immunofluorescence, showed that in 50 to $60 \%$ of the cells the levels of the endogenous $\operatorname{PrP}^{\mathrm{c}}$ were dramatically decreased 2 days (not shown) or 3 days after transfection (Fig. 5A) as compared to control cells, i. e. cells transfected with an inefficient mouse $\operatorname{PrP}^{\mathrm{C}}$-siRNA or with a scramble siRNA or cells incubated with Oligofectamine only, and returned to the control levels from 4 days after transfection (not shown). 
A
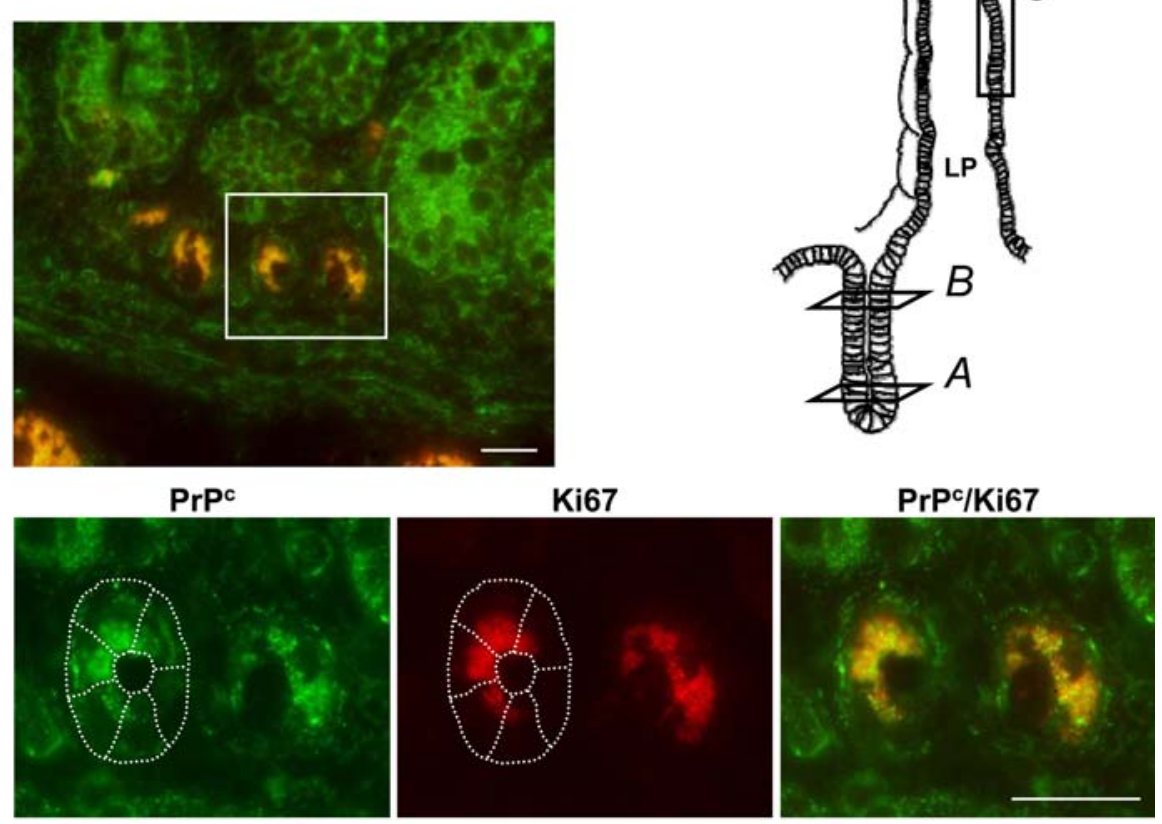

B

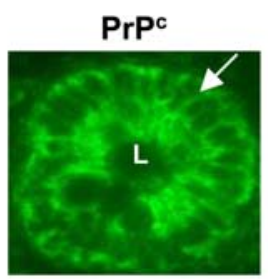

C

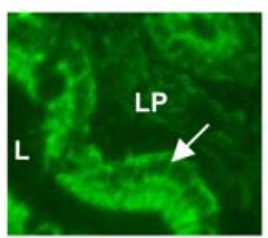

Ki67
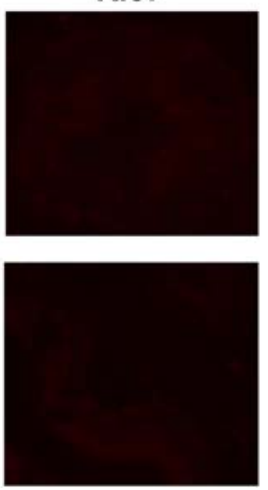

PrPc/Ki67/DAPI
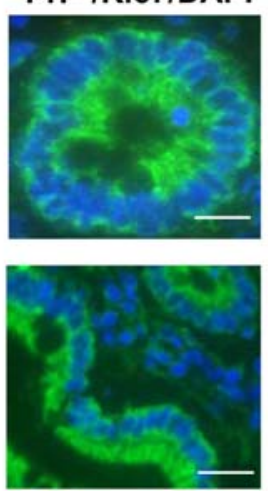

Figure 2. Expression and localization of $\operatorname{PrP}^{\mathbf{c}}$ and Ki67 in normal human intestinal epithelium. Immunofluorescence labeling of PrP ${ }^{c}$ (green, 12F10 antibody) and Ki67 (red) was performed on thin sections of paraffin-embedded pieces of jejunum. Images in A, B and C correspond to crypts, crypt-villus transition compartment and villus respectively, as indicated on the scheme. Lower panels in A correspond to an enlargement of the crypt zone shown above. In B and C, nuclei were stained with DAPI. Note the colocalization of PrP ${ }^{\mathrm{C}}$ and Ki67 in the nuclei of crypt cells and the cytoplasmic and membrane localization of $\mathrm{PrP}^{\complement}$ in Ki67 negative epithelial cells. LP, lamina propria; L, lumen. Arrows point out cell-cell junctions of the epithelium. Bars: $20 \mu \mathrm{m}$.

doi:10.1371/journal.pone.0003000.g002

In a first attempt, the junctional state was assessed 3 and 7 days after transfection by the analysis of the expression and localization of E-cadherin, which does not interact with $\operatorname{PrP}^{\mathrm{c}}$ but is the most studied marker of cell-cell junctions. Three days after transfection (i.e 6 days after seeding), junctional complexes were already formed in the center of expanding cell clusters. In cells where $\operatorname{PrP}^{\mathrm{c}}$ expression was specifically impaired, the E-cadherin still localized to the lateral membranes of adjacent cells but its labeling intensity was decreased (Fig. 5A). Moreover, in the same fields, the cells appeared enlarged as compared with the three control conditions, as clearly noticeable in phase contrast picture (Fig. 5A). When the effect of human siRNAs on the expression of $\operatorname{PrP}^{\mathrm{c}}$ was no longer observed (day 7, Fig. 5A), the size of the cells and the amount of the junctional E-cadherin were rescued. We then analyzed the expression and the sub-cellular localization of the junctional partners of $\operatorname{PrP}^{\mathrm{c}}$ by immunofluorescence (Fig. 5B). To better compare cells that still expressed $\operatorname{PrP}^{\mathrm{c}}(40-50 \%)$ or not $(50-60 \%)$, fields that combined the two cell populations of human PrPcsiRNA transfected cells are shown (Fig 5B, right panels) along with pictures representative of the results obtained in the three control conditions (Fig. 5B, left panels). Cells exhibiting a net decrease of $\mathrm{PrP}^{\mathrm{c}}$ levels were systematically enlarged. In these cells, the amount and/or the sub-cellular localization of the junctional partners of $\operatorname{PrP}^{c}$ were modified: c-Src was found essentially intracellular, 

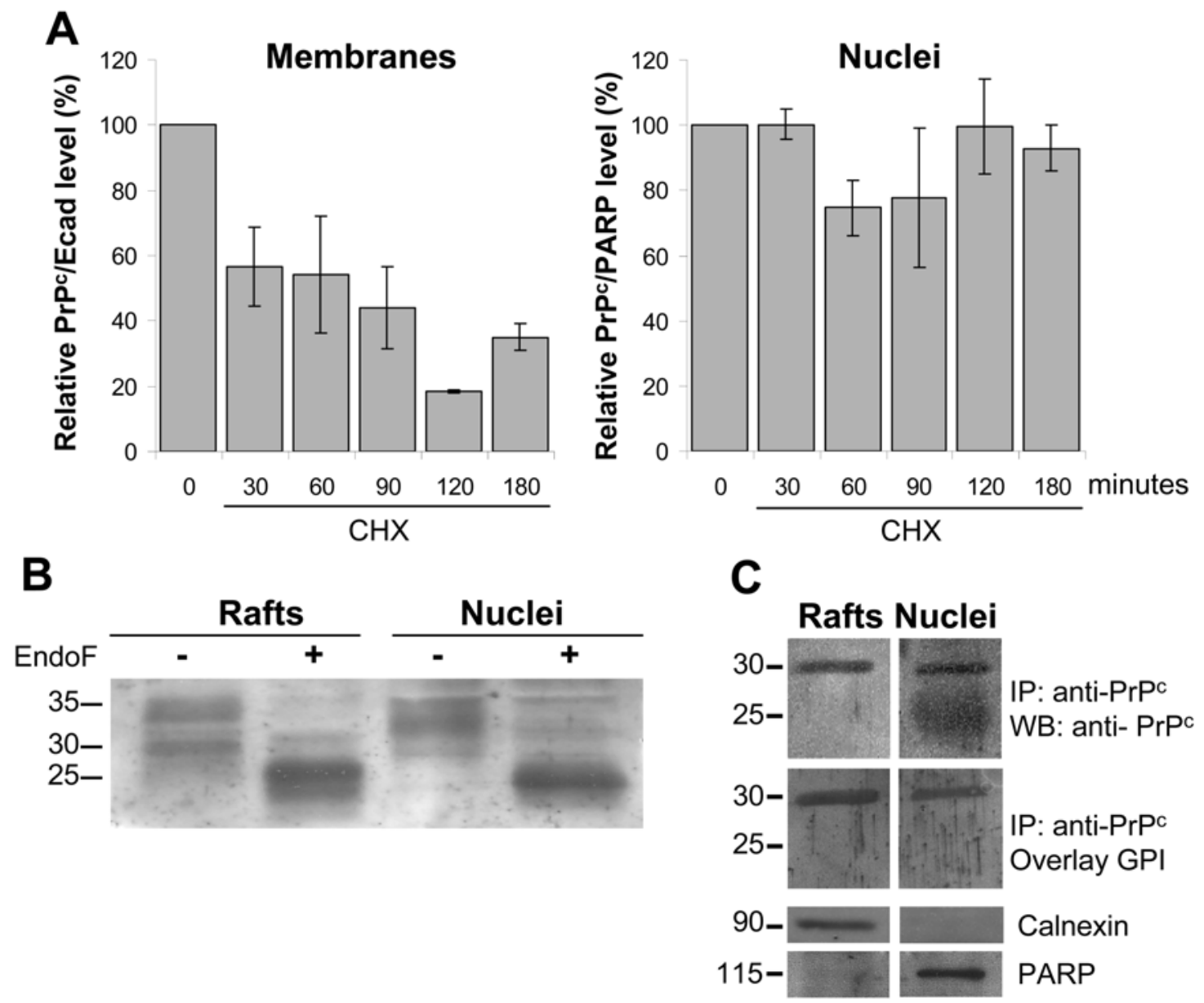

Figure 3. Biochemical characterization of membrane- and nucleus-associated PrP ${ }^{c}$ isoforms. (A): Stability of membrane and nuclear PrP ${ }^{c}$ was analyzed by western blot after treatment of the cells with cycloheximide for the indicated times and purification of membranes and nuclei. Bands obtained in western blots (SAF 32 antibody) were quantified by scanning densitometry. E-cadherin and PARP were used to normalize the values obtained in membrane and nuclear fractions respectively, since both proteins were found stable for the duration of $\mathrm{CHX}$ treatment. Histograms correspond to the ratio (\%) between PrPc and E-cadherin or PARP from the corresponding scanned bands at each time (mean \pm SD from 3 independent experiments), the value obtained at time 0 being set at 100. (B): To determine the glycosylation state, rafts and nuclear extracts were treated $(+)$ or not $(-)$ with endo $F$ and $\operatorname{PrP}^{c}$ was analyzed by western blot (SAF 32 antibody). Molecular weight in KDa are indicated (C): The presence of a GPI anchor was analyzed after immunoprecipitation of PrP ${ }^{\complement}$ from rafts or nuclear extracts, SDS-PAGE, transfer and overlay with biotinylated proaerolysin bacterial toxin. To check the purity of the extracts, the expression of calnexin (membrane marker) and PARP (nuclear marker) was analyzed by western blot. Molecular weight in KDa are indicated.

doi:10.1371/journal.pone.0003000.g003

desmoglein, plakoglobin and desmoplakin labelings were lowered, and numerous actin stress fibers could be visualized in large cells that no longer expressed $\mathrm{PrP}^{\mathrm{c}}$.

The role of $\operatorname{PrP}^{\mathrm{c}}$ on structural organization of cell-cell junctions was further analyzed in intestinal epithelium of $\operatorname{PrP}^{\mathrm{c}}$ knock out mice. Ultrastructural analysis revealed drastic changes in the length of the desmosomal plaque (Fig. 5C upper panel), which was not compensated by their number (not shown). Quantification of the length of desmosomes indicated a distribution of their size concentrated between 83 to $134 \mathrm{~nm}$ in knock out mice instead of 100 to $183 \mathrm{~nm}$ in wild type mice (Fig. 5C lower panel).

$\operatorname{PrP}^{c}$ invalidation impairs completion of cell division and results in a shortening of intestinal villi

When compared to the three control conditions, we noticed an enlargement of human $\operatorname{PrP}^{\mathrm{C}}$ siRNA-treated dividing enterocytes (Fig. 5A) that could reflect the impact of $\mathrm{PrP}^{\mathrm{C}}$-expression on cell proliferation. Analysis of cell growth (Fig. 6A) showed an arrest of the increase in cell numbers between 2 and 3 days after transfection, i.e during the period when $\operatorname{PrP}^{c}$ expression was significantly decreased by human siRNAs. Surprisingly, DAPI staining of the nuclei showed that growth arrest was paralleled with a net increase of the number of mitosis, without apoptosis, in cells that did not express $\operatorname{PrP}^{\mathrm{c}}$ anymore (Fig. 6B). In parallel, the morphological examination of the intestinal epithelium of $\operatorname{PrP}^{\mathrm{c}}$ knock out mice revealed a net decrease in the length of the villi in both duodenum and jejunum segments in comparison with their wild type counterparts (Fig. 6C). To analyze the impact of $\operatorname{PrP}^{c}$ expression on cell proliferation within the intestinal epithelium, $\operatorname{PrP}^{\mathrm{C}}$ knock out and wild type mice were pulse-labeled with $\mathrm{BrdU}$ for 1.5 hour prior to sacrifice. No significant difference in the number of BrdU-labeled cells in sections of jejunal crypts was observed between wild type and knock out mice (Fig. 6D), suggesting that $\mathrm{S}$ phase was not affected. By contrast, labeling of the mitosis-associated phospho-H3 revealed a net increase of mitotic cells in the crypt compartments of intestine from $\operatorname{PrP}^{\mathrm{c}}$ knock out mice as compared with wild type mice, while no obvious change in the size of the crypts was observed. 
Table 1. PrPc partners in rafts.

\begin{tabular}{llll}
\hline & & & \\
\hline Identified proteins & Accession $\mathbf{n}^{\mathbf{0}}$ & Mr & $\begin{array}{l}\text { Peptide } \\
\text { matches }\end{array}$ \\
\hline Desmoglein 2 & gi 416178 & 122 & 9 \\
Plakophilin 2a & gi 1871541 & 93 & 4 \\
Plakoglobin & gi 15080189 & 82 & 9 \\
Desmoyokin & gi 627367 & 312 & 17 \\
Desmoplakin & gi 3702136 & 332 & 38 \\
gamma-actin & gi 17511847 & 42 & 8 \\
beta-actin & gi 16359158 & 42 & 10 \\
alpha2 Spectrin & gi 1805280 & 285 & 10 \\
Annexin isoform 2 & gi 16306978 & 39 & 18 \\
\hline
\end{tabular}

Raft extracts from differentiated Caco-2/TC7 cells (10 days) were

immunoprecipitated with anti $\operatorname{PrP}^{c}$ antibodies. The presence of $\operatorname{PrP}^{c}$ in the resulting material was checked by western blot before identification of the proteins interacting with $\mathrm{PrP}^{\mathrm{C}}$ by liquid chromatography-tandem MS (MS/MS)

The number of peptide matches that was obtained after trypsination for each protein as well as the accession number $(\mathrm{NCBI})$ and the molecular weight $(\mathrm{Mr})$ are reported.

doi:10.1371/journal.pone.0003000.t001

\section{Discussion}

Our present results demonstrate that the cellular prion protein, $\operatorname{PrP}^{c}$, exhibits a dual distribution between the nucleus, in actively dividing cells, and cell-cell adhesion sites in polarized/differentiated cells. Interestingly, the membrane $\operatorname{PrP}^{\mathrm{c}}$ interacts with desmosomal proteins as well as with actin and actin-binding proteins at cell-cell junctions. Furthermore, we show that down regulation of $\operatorname{PrP}^{\mathrm{c}}$ expression in Caco-2/TC7 enterocytes lead to a complex pattern of alterations in both cell architecture and completion of the cell division process. These results are strengthened by the analysis of the intestinal epithelium of $\operatorname{PrP}^{\mathrm{c}}$ knock out mice, in which intestinal villi were found shortened and the size of enterocyte desmosomes decreased as compared to wild type mice.
Contrary to abnormal prion proteins [36-38], a targeting of the normal $\operatorname{PrP}^{\mathrm{c}}$ isoform to the nucleus has been rarely reported, $[39,40]$. We demonstrate here that in intestinal epithelial cells, such a nuclear targeting is observed only in actively dividing cells, both in cultured enterocytes and in the intestinal epithelium in vivo. The characterization of the nuclear pattern of $\operatorname{PrP}^{\mathrm{c}}$ isoforms revealed that it is similar to that of membrane-associated $\operatorname{PrP}^{c}$ in terms of glycosylation and presence of a GPI anchor. Analysis of protein stability shows a much longer half-life of $\operatorname{PrP}^{c}$ in the nucleus than in plasma membrane, where junctional proteins are rapidly recycled. Nuclear $\operatorname{PrP}^{\mathrm{c}}$ stability could rely on the association with particular sub-nuclear compartments, such as PML bodies [41], a localization compatible with the pattern of nuclear $\operatorname{PrP}^{\mathrm{c}}$ staining that we observed. Contrasting with the misfolded protein [38], we show an exclusion of normal $\operatorname{PrP}^{\mathrm{c}}$ from the nucleolus. Altogether, our results asked the question of its biological role in the nucleus of dividing cells. Upon $\operatorname{PrP}^{\mathrm{c}}$ down regulation in cultured enterocytes, we observed modifications of cell morphology and an arrest of cell growth. This observation was consistent with the decreased villus size of the intestinal epithelium that we observed in $\operatorname{PrP}^{\mathrm{c}}$ null mice. In several mouse models, it has been shown that reduced intestinal crypt cell proliferation is associated with shorter villi $[42,43]$. The growth arrest observed in $\operatorname{PrP}^{c}$ siRNA-transfected cells was paralleled by an increase of mitotic cells. Further analysis of cell cycle perturbations was rendered difficult by the moderate transfection efficiency of Caco-2/TC7 cells by siRNA (50\%). Nevertheless, the absence of $\mathrm{S}$ phase overt perturbation in crypts from $\operatorname{PrP}^{\mathrm{c}}$ null mice, as shown by BrdU incorporation experiments, along with the important increase of the number of mitotic cells in the crypt compartment suggest that $\operatorname{PrP}^{\mathrm{c}}$ invalidation would affect the mitosis process. $\operatorname{PrP}^{c}$ has been shown to associate with tubulin [44] [45]. In addition, desmoplakin, that we identified as a $\operatorname{PrP}^{c}$ partner, participates to the organization of microtubules in keratinocytes, through the recruitment at cell-cell junctions of a centrosomal protein, which is required for microtubule anchoring [46]. However, it cannot be concluded yet whether all the phases of mitosis or more particularly the last step of cytokinesis are slowed down through $\operatorname{PrP}^{\mathrm{c}}$ invalidation.
A

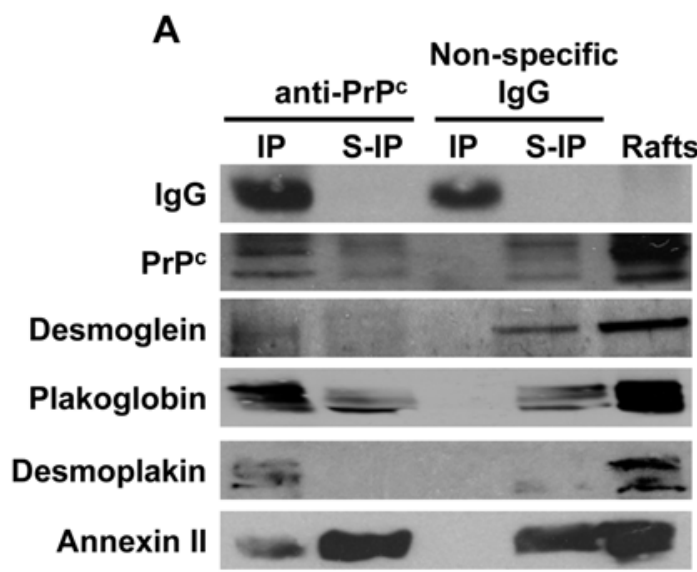

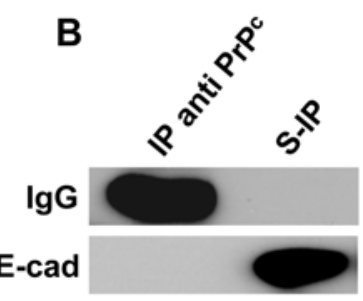

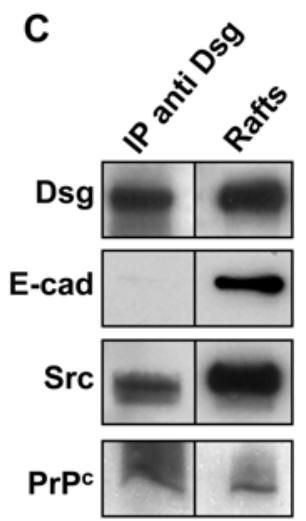

Figure 4. Immunodetection of PrPc-associated desmosomal proteins in differentiated Caco-2/TC7 cells. (A): Proteins that were found to interact with $\operatorname{PrP}^{c}$ through proteomic study (Table 1) were analyzed by western blot in rafts, and in immunoprecipitated material (IP) or in supernatants of immunoprecipitations (S-IP) from raft extracts of differentiated cells (day 10). Immunoprecipitations were performed with rabbit anti$\mathrm{PrP}^{\mathrm{C}}$ antibodies (Ab703) or with non-specific rabbit immunoglobulins as a control. (B): The presence of E-cadherin, which was not identified as a PrP ${ }^{\mathrm{C}}$ partner, was checked, after immunoprecipitation with anti-PrP ${ }^{c}$, in immunoprecipitated material (IP) and immunoprecipitation supernatant (S-IP). Note that E-cadherin is only recovered in immunoprecipitation supernatant. (C): desmoglein (Dsg), Src, $\operatorname{PrP}^{\mathrm{C}}$ and E-cadherin (E-cad) were analyzed by western blot in raft extracts (right lane) or after their immunoprecipitation with anti-desmoglein antibodies (left panel). Note the coimmunoprecipitation of desmoglein, $\mathrm{c}$-Src and $\mathrm{PrP}^{\mathrm{C}}$ and the absence of E-cadherin co-immunoprecipitation. doi:10.1371/journal.pone.0003000.g004 
A

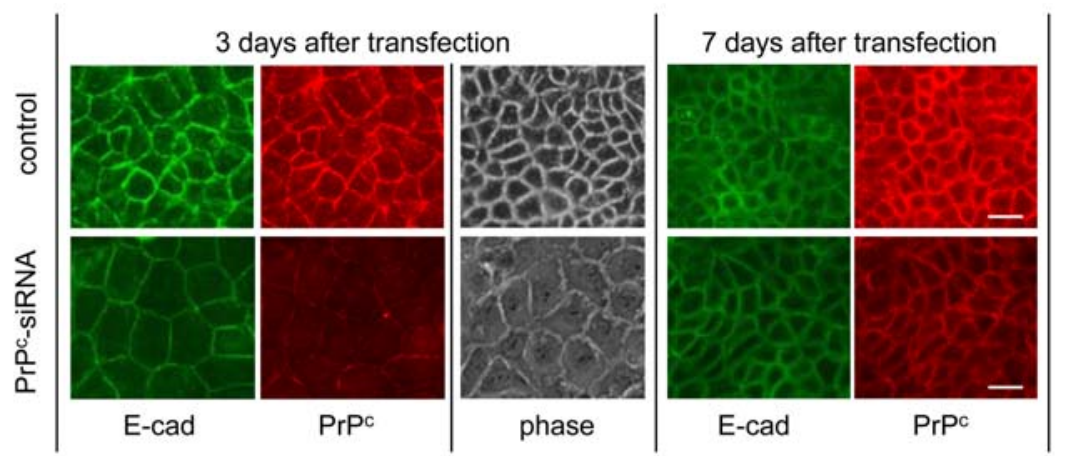

B

control
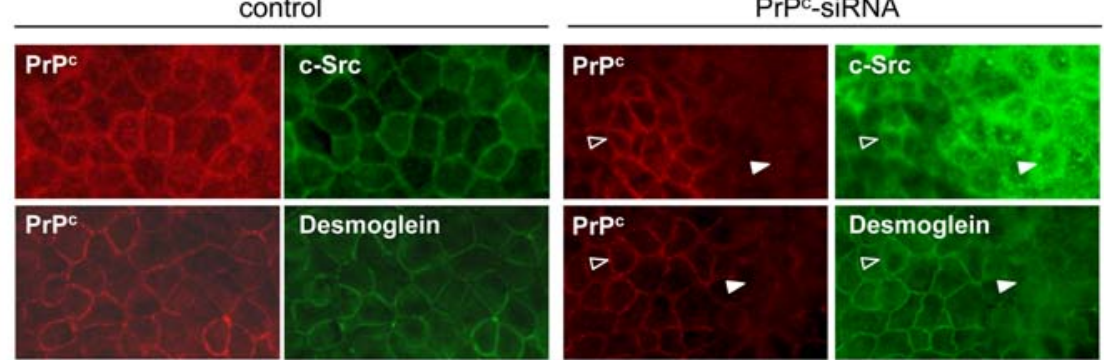

Desmoglein
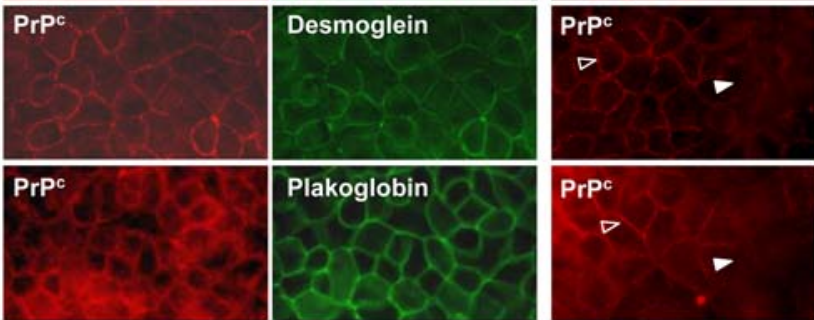

Desmoglein
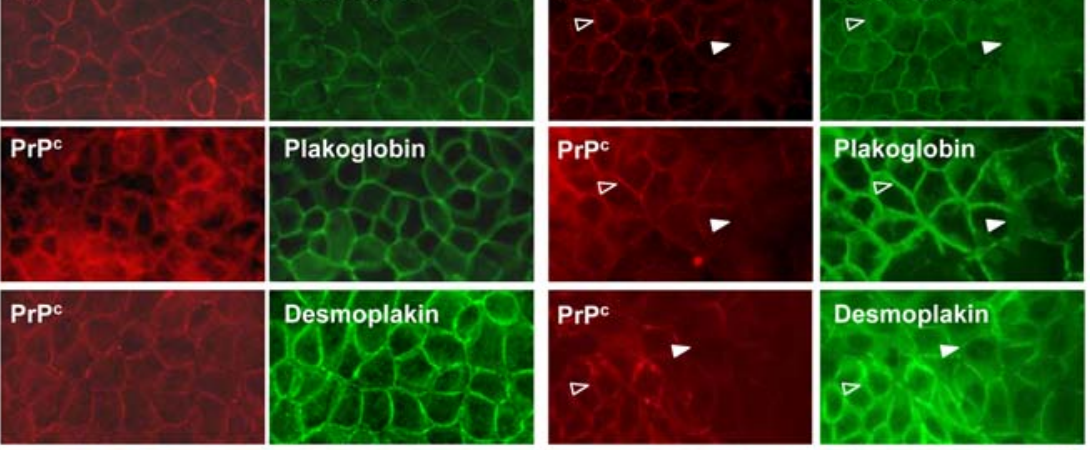

Desmoplakin
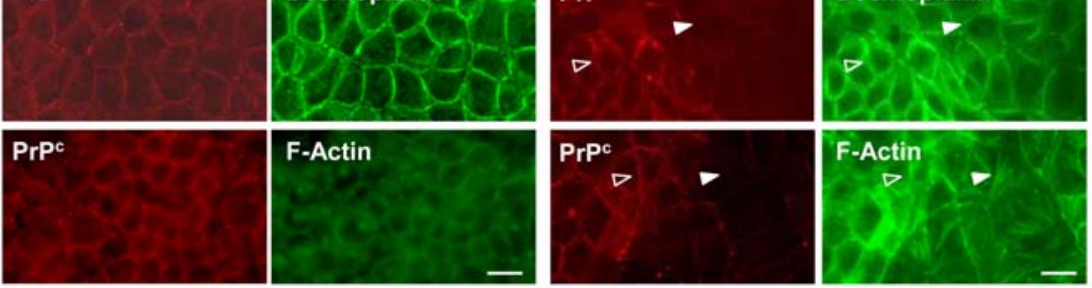

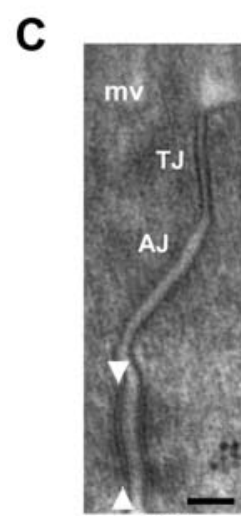

WT

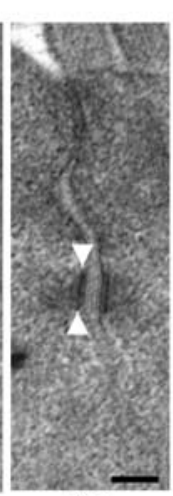

$\mathrm{KO}$

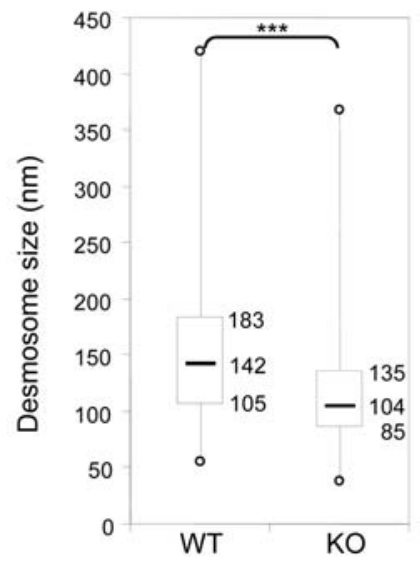

Figure 5. Effects of $\operatorname{PrP}^{c}$ invalidation on the sub-cellular localization of junctional PrPc partners and on desmosome structure. (A): Caco-2/TC7 cells were transfected by PrPC-siRNA 3 days after seeding and the expression and localization of PrP (red, $12 \mathrm{~F} 10$ antibody) and E-cadherin (green) were analyzed 3 days and 7 days after transfection in control (Oligofectamine or mouse PrP ${ }^{\mathrm{C}}$-siRNA transfected cells) or human PrPc-siRNA transfected cells. Phase contrast image (phase) shows the morphology of the cell layer. (B): Immunofluorescence labeling of PrPc (red), c-Src, desmoglein, plakoglobin, desmoplakin and F-actin (green) was performed in control cells (left panels) and in human PrPC-siRNA transfected cells 3 days after transfection (right panels). Control pictures are representative of the results obtained with scramble siRNA or with mouse PrP ${ }^{c}$ si-RNA or with cells incubated with the transfection agent, Oligofectamine. In human PrPc-siRNA transfected cells, fields combining zones where PrPc was still present (open arrowhead) and zones where it was switched off (closed arrowhead) are shown. Note the difference in cell shape between both areas. Mouse $12 \mathrm{~F} 10$ anti-PrP ${ }^{c}$ antibody was used for immunofluorescence labeling of $\mathrm{PrP}^{\mathrm{C}}$ except for co-labeling with plakoglobin, in which rabbit polyclonal anti-PrP ${ }^{c}$ Ab703 antibodies were used. Bar: $20 \mu \mathrm{m}$. (C): Desmosomes were analyzed by electron microscopy in intestinal epithelium sections from PrPc knock out (KO) and wild type (WT) mice. Note the electron-dense desmosomal plaque which was shorter in PrP $\mathrm{P}^{\mathrm{C}}$-knock-out than in wild type mice (arrowheads). mv: microvilli, TJ: tight junction, AJ: adherens junction. Bar: $100 \mathrm{~nm}$. Quantification of desmosome size was represented in the lower graph. Box and whisker plots show median desmosomal length (horizontal line), 25th and 75th centiles (box), and range (whiskers) in the wild type (WT, $n=135$, three mice) and PrPc-knock out mice (KO, $n=135$, three mice), ${ }^{* * *} p<0.001$.

doi:10.1371/journal.pone.0003000.g005 
A
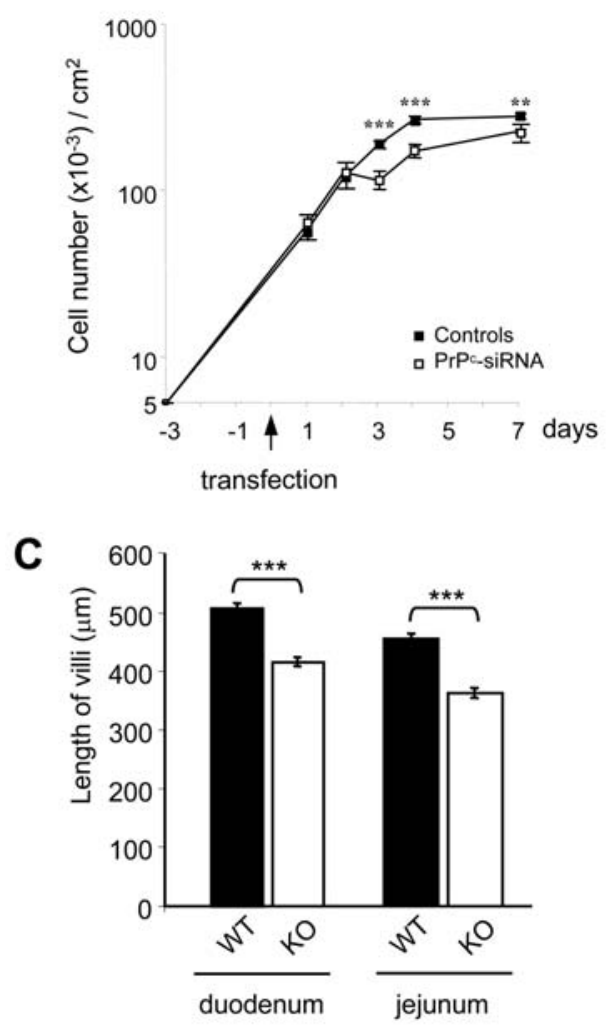

D

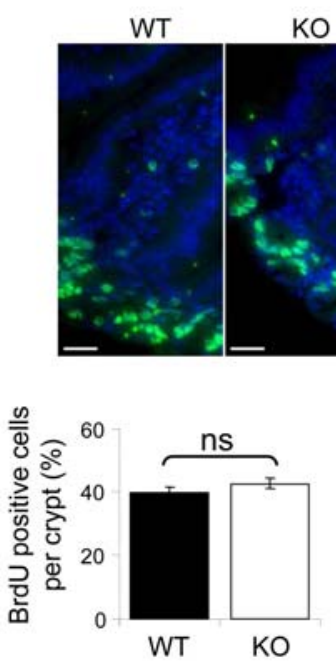

B
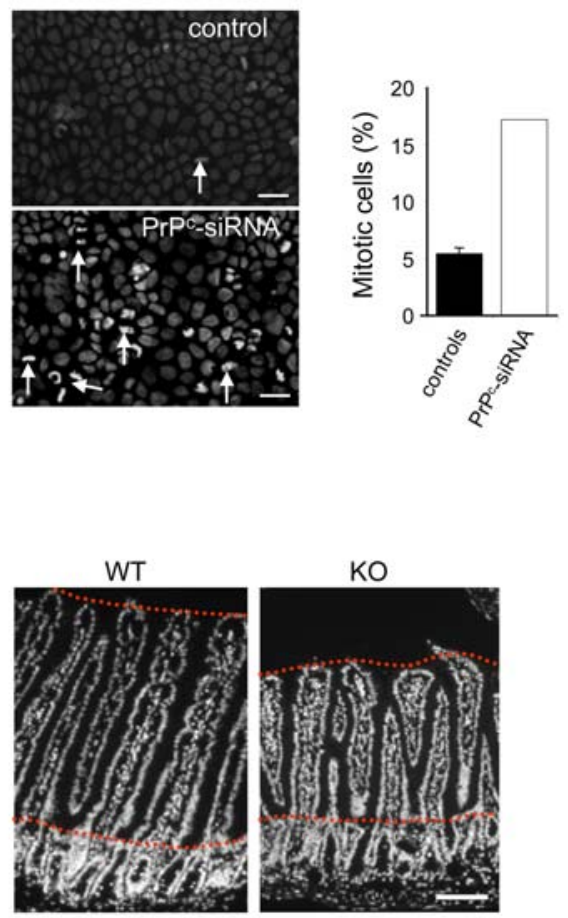

jejunum
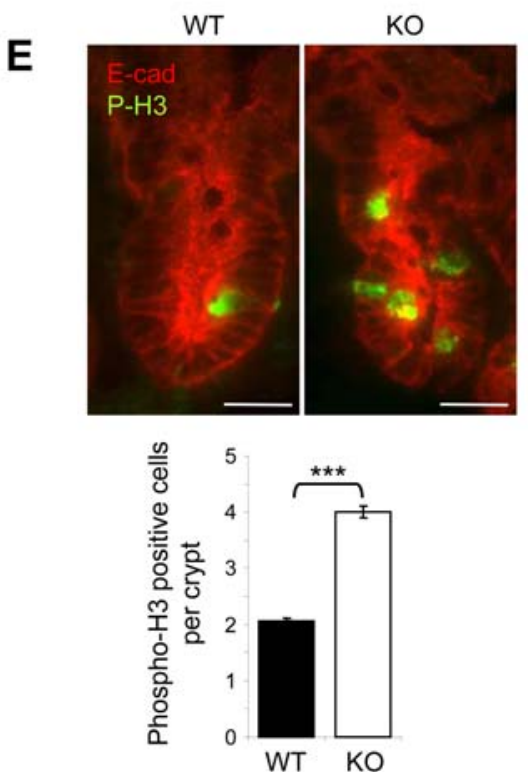

Figure 6. Effects of PrPc invalidation on the completion of cell division and length of intestinal villi. (A): Caco-2/TC7cells were numbered all along the experiment from 3 days before transfection $(-3)$ to 7 days after transfection. Controls combine results obtained in the three conditions described in figure 5 (scramble siRNA, mouse $\operatorname{PrP}^{c}$ si-RNA, Oligofectamine). PrP ${ }^{c}$-siRNA condition corresponds to the results obtained after specific human PrPC-siRNA transfection. Results are from 4 independent experiments. ${ }^{* *} p<0.01,{ }^{* * *} p<0.001$. (B): In the same experiments, cells that showed nuclear division phases were counted after staining with DAPI. In the left panels arrows point examples of metaphases or telophases that were counted. In each condition, 1000 cells were analyzed and the percentage of mitotic cells in controls (black bar, same three conditions as above) or in human PrPC-siRNA (white bar) transfected cells is reported in the right panel. Error bar shown in histogram of controls represents the statistical analyses performed when combining the three control conditions. C: sections of duodenum and jejunum fragments from wild type (WT) and PrP ${ }^{c}$ knock out (KO) mice ( 2 mice in each group) were stained with DAPI (right panel, bar: $100 \mu \mathrm{m}$ ). Sixty villi were measured for each mouse and fragment. No difference was observed between the 2 mice of each group (not shown), but significant differences $(* * * p<0.001)$ were obtained between wild type (black bars) and knock out mice (white bars) in both duodenum and jejunum fragments. (D): After 1.5 hour BrdU intraperitoneal injection, sections from the jejunum fragment of wild type (WT) and knock out (KO) mice were performed. Nuclei were visualized with DAPI staining (blue). BrdU-stained proliferating cells (green) are limited to the crypts in wild type and knock out animals. Bars: $10 \mu \mathrm{m}$. Knock out mice display similar number of positive BrdU cells per crypt as compared with wild type mice (quantification in the right panel graph). No significant difference was revealed by statistical analysis (ns, student's $t$ test). (E): Immunofluorescence analyses of phospho H3 (green) and E-cadherin (red) were performed on intestine sections from wild type (WT) or PrPc knock out (KO) mice (3 mice in each group). Pictures of crypt staining are shown (upper panels; bars: $10 \mu \mathrm{m})$ and the number of phospho-H3 positive cells per crypt is reported (155 crypts were counted in each group). ${ }^{* * *} \mathrm{p}<0.001$. doi:10.1371/journal.pone.0003000.g006 
Another important finding of our study is the identification of desmosomal proteins as $\operatorname{PrP}^{\mathrm{c}}$ partners at cell-cell junctions. We had already identified c-Src kinase as a partner of $\operatorname{PrP}^{c}$ in polarized enterocytes and demonstrated that $\operatorname{PrP}^{\mathrm{c}}$ does not interact with E-cadherin [24], asking the question of the partner that could link $\operatorname{PrP}^{c}$, which is anchored in the outer leaflet of the lateral membrane, to Src, which is localized in the inner one. Our data are consistent with the existence of a molecular complex in which the transmembrane desmosomal cadherin desmoglein is this link between $\operatorname{PrP}^{\mathrm{c}}$ and c-Src. Involvement of $\mathrm{PrP}^{\mathrm{c}}$ in the regulation of desmosome organization, and more generally in cell architecture, is further supported by our demonstration of alterations in the junctional targeting of Src and desmosomal proteins upon $\operatorname{PrP}^{\mathrm{c}}$ down-regulation by siRNA during the establishment of enterocyte cell-cell contacts. Importantly, absence of $\mathrm{PrP}^{\mathrm{c}}$ in vivo results in alterations in the size of desmosomes in intestinal epithelial cells. This structural perturbation could reflect modifications of assembly and/or stability of the desmosomal-protein complex in the absence of $\operatorname{PrP}^{\mathrm{c}}$, as described for invalidation or mutation of other desmosome-associated proteins, such as desmoglein, plakoglobin or plakophilin families, in murine models or human pathologies (for review, see [47]). Desmosomal proteins have emerged as adhesion molecules that not only play critical structural roles but are also involved in signaling pathways [48]. Our data further support the hypothesis of the involvement of $\mathrm{PrP}^{\mathrm{c}}$, in association with its desmosomal partners, in a signaling platform of the junctional state.

In conclusion, our results indicate that the normal cellular prion isoform $\mathrm{PrP}^{\mathrm{c}}$, by its differential nuclear or junctional localization,

\section{References}

1. Prusiner SB, Scott MR, DeArmond SJ, Cohen FE (1998) Prion protein biology. Cell 93: 337-348.

2. Bueler H, Aguzzi A, Sailer A, Greiner RA, Autenried P, et al. (1993) Mice devoid of PrP are resistant to scrapie. Cell 73: 1339-1347.

3. Prusiner SB (1998) The prion diseases. Brain Pathol 8: 499-513.

4. Weissmann C, Bueler H, Fischer M, Sailer A, Aguzzi A, et al. (1994) PrPdeficient mice are resistant to scrapie. Ann N Y Acad Sci 724: 235-240.

5. Bendheim PE, Brown HR, Rudelli RD, Scala LJ, Goller NL, et al. (1992) Nearly ubiquitous tissue distribution of the scrapie agent precursor protein. Neurology 42: $149-156$.

6. Cashman NR, Loertscher R, Nalbantoglu J, Shaw I, Kascsak RJ, et al. (1990) Cellular isoform of the scrapie agent protein participates in lymphocyte activation. Cell 61: 185-192.

7. Horiuchi M, Yamazaki N, Ikeda T, Ishiguro N, Shinagawa M (1995) A cellular form of prion protein (PrPC) exists in many non-neuronal tissues of sheep. J Gen Virol 76(Pt 10): 2583-2587.

8. Pammer J, Cross HS, Frobert Y, Tschachler E, Oberhuber G (2000) The pattern of prion-related protein expression in the gastrointestinal tract. Virchows Arch 436: 466-472.

9. Sugaya M, Nakamura K, Watanabe T, Asahina A, Yasaka N, et al. (2002) Expression of cellular prion-related protein by murine Langerhans cells and keratinocytes. J Dermatol Sci 28: 126-134.

10. Brockes JP (1999) Topics in prion cell biology. Curr Opin Neurobiol 9: 571-577.

11. Meyer RK, Lustig A, Oesch B, Fatzer R, Zurbriggen A, et al. (2000) A monomer-dimer equilibrium of a cellular prion protein (PrPC) not observed with recombinant PrP. J Biol Chem 275: 38081-38087.

12. Gauczynski S, Hundt C, Leucht C, Weiss $S$ (2001) Interaction of prion proteins with cell surface receptors, molecular chaperones, and other molecules. Adv Protein Chem 57: 229-272.

13. Gauczynski S, Peyrin JM, Haik S, Leucht C, Hundt C, et al. (2001) The 37$\mathrm{kDa} / 67-\mathrm{kDa}$ laminin receptor acts as the cell-surface receptor for the cellular prion protein. Embo J 20: 5863-5875.

14. Hundt C, Peyrin JM, Haik S, Gauczynski S, Leucht C, et al. (2001) Identification of interaction domains of the prion protein with its $37-\mathrm{kDa} / 67-$ kDa laminin receptor. Embo J 20: 5876-5886.

15. Martins VR, Mercadante AF, Cabral AL, Freitas AR, Castro RM (2001) Insights into the physiological function of cellular prion protein. Braz J Med Biol Res 34: 585-595.

16. Rieger R, Edenhofer F, Lasmezas CI, Weiss S (1997) The human 37-kDa laminin receptor precursor interacts with the prion protein in eukaryotic cells. Nat Med 3: 1383-1388. must be considered as a potential actor of the balance between proliferation and polarization/differentiation of epithelial cells, through interaction with $\mathrm{c}$-Src and with desmosome- and cytoskeleton-associated proteins. As such $\mathrm{PrP}^{\mathrm{c}}$ could be involved in the homeostasis of renewing epithelia.

\section{Acknowledgments}

Human intestine sections were obtained from Pr E. Leteurtre (Service d'Anatomie et de Cytologie Pathologiques, Pôle Biologie Pathologie, parc Eurasanté, CHRU, avenue Oscar Lambret, 59037 Lille cedex; Faculté de médecine Henri Warembourg, 59045 Lille cedex; Centre de Recherche Jean-Pierre AUBERT - JPARG Inserm U837, Equipe "Mucines, différenciation et cancérogenèse épithéliales", Place de Verdun, 59045 Lille cedex). GFP-PrP ${ }^{c}$ plasmid was obtained from M.A. Prado (Departamento de Bioquimica-Imunologia, Instituto de Ciencias Biologicas, Universidade Federal de Minas Gerais, Belo Horizontz, Brazil), and the biotinylated pro-aerolysin bacterial toxin was a kind gift from Gisou van der Goot (Ecole Polytechnique de Lausanne, CH-1015 Lausanne, Switzerland). We thank Julie Biscan (UMR S 872, CRC, Paris) for cryostat sections of mouse intestine. Confocal and electron microscopy analyzes were performed using the facilities of Centre de Recherche des Cordeliers, UMR S 872.

\section{Author Contributions}

Conceived and designed the experiments: EM SF MR ST CC. Performed the experiments: EM SF CSP CPT CP LY MPR MR ST CG. Analyzed the data: EM SF CSP CPT GP DL LY MPR MR ST CG. Contributed reagents/materials/analysis tools: DL AMF. Wrote the paper: MPR JC MR ST CG.

17. Schmitt-Ulms G, Legname G, Baldwin MA, Ball HL, Bradon N, et al. (2001) Binding of neural cell adhesion molecules (N-CAMs) to the cellular prion protein. J Mol Biol 314: 1209-1225.

18. Shmakov AN, Bode J, Kilshaw PJ, Ghosh S (2000) Diverse patterns of expression of the $67-\mathrm{kD}$ laminin receptor in human small intestinal mucosa: potential binding sites for prion proteins? J Pathol 191: 318-322.

19. Spielhaupter C, Schatzl HM (2001) PrPC directly interacts with proteins involved in signaling pathways. J Biol Chem 276: 44604-44612.

20. Mouillet-Richard S, Ermonval M, Chebassier C, Laplanche JL, Lehmann S, et al. (2000) Signal transduction through prion protein. Science 289: 19251928 .

21. Schneider B, Mutel V, Pietri M, Ermonval M, Mouillet-Richard S, et al. (2003) NADPH oxidase and extracellular regulated kinases $1 / 2$ are targets of prion protein signaling in neuronal and nonneuronal cells. Proc Natl Acad Sci U S A 100: 13326-13331

22. Brown DR, Nicholas RS, Canevari L (2002) Lack of prion protein expression results in a neuronal phenotype sensitive to stress. J Neurosci Res 67: 211-224.

23. Sarnataro D, Paladino S, Campana V, Grassi J, Nitsch L, et al. (2002) PrPC is sorted to the basolateral membrane of epithelial cells independently of its association with rafts. Traffic 3: 810-821.

24. Morel E, Fouquet S, Chateau D, Yvernault L, Frobert Y, et al. (2004) The cellular prion protein $\operatorname{PrPc}$ is expressed in human enterocytes in cell-cell junctional domains. J Biol Chem 279: 1499-1505.

25. Frame MC, Fincham VJ, Carragher NO, Wyke JA (2002) v-Src's hold over actin and cell adhesions. Nat Rev Mol Cell Biol 3: 233-245.

26. Viegas P, Chaverot N, Enslen H, Perriere N, Couraud PO, et al. (2006) Junctional expression of the prion protein PrPC by brain endothelial cells: a role in trans-endothelial migration of human monocytes. J Cell Sci 119: 4634-4643.

27. Stappenbeck TS, Wong MH, Saam JR, Mysorekar IU, Gordon JI (1998) Notes from some crypt watchers: regulation of renewal in the mouse intestinal epithelium. Curr Opin Cell Biol 10: 702-709.

28. Chantret I, Rodolosse A, Barbat A, Dussaulx E, Brot-Laroche E, et al. (1994) Differential expression of sucrase-isomaltase in clones isolated from early and late passages of the cell line Caco-2: evidence for glucose-dependent negative regulation. J Cell Sci 107(Pt 1): 213-225.

29. Abrami L, Fivaz M, Glauser PE, Parton RG, van der Goot FG (1998) A poreforming toxin interacts with a GPI-anchored protein and causes vacuolation of the endoplasmic reticulum. J Cell Biol 140: 525-540.

30. Lee KS, Magalhaes AC, Zanata SM, Brentani RR, Martins VR, et al. (2001) Internalization of mammalian fluorescent cellular prion protein and N-terminal deletion mutants in living cells. J Neurochem 79: 79-87. 
31. Kalina M, Pease DC (1977) The preservation of ultrastructure in saturated phosphatidyl cholines by tannic acid in model systems and type II pneumocytes. J Cell Biol 74: 726-741.

32. Macdonald JL, Pike LJ (2005) A simplified method for the preparation of detergent-free lipid rafts. J Lipid Res 46: 1061-1067.

33. Fevrier B, Vilette D, Archer F, Loew D, Faigle W, et al. (2004) Cells release prions in association with exosomes. Proc Natl Acad Sci U S A.

34. Rouvinski A, Gahali-Sass I, Stav I, Metzer E, Atlan H, et al. (2003) Both raftand non-raft proteins associate with CHAPS-insoluble complexes: some APP in large complexes. Biochem Biophys Res Commun 308: 750-758.

35. Benaud C, Gentil BJ, Assard N, Court M, Garin J, et al. (2004) AHNAK interaction with the annexin 2/S100A10 complex regulates cell membrane cytoarchitecture. J Cell Biol 164: 133-144.

36. Crozet C, Vezilier J, Delfieu V, Nishimura T, Onodera T, et al. (2006) The truncated 23-230 form of the prion protein localizes to the nuclei of inducible cell lines independently of its nuclear localization signals and is not cytotoxic. Mol Cell Neurosci 32: 315-323.

37. Gu Y, Hinnerwisch J, Fredricks R, Kalepu S, Mishra RS, et al. (2003) Identification of cryptic nuclear localization signals in the prion protein. Neurobiol Dis 12: 133-149.

38. Mange A, Crozet C, Lehmann S, Beranger F (2004) Scrapie-like prion protein is translocated to the nuclei of infected cells independently of proteasome inhibition and interacts with chromatin. J Cell Sci 117: 2411-2416.

39. Rybner C, Finel-Szermanski S, Felin M, Sahraoui T, Rousseau C, et al. (2002) The cellular prion protein: a new partner of the lectin CBP70 in the nucleus of NB4 human promyelocytic leukemia cells. J Cell Biochem 84: 408-419.
40. Hosokawa T, Tsuchiya K, Sato I, Takeyama N, Ueda S, et al. (2008) A monoclonal antibody (1D12) defines novel distribution patterns of prion protein $(\operatorname{PrP})$ as granules in nucleus. Biochem Biophys Res Commun 366: 657-663.

41. Villagra NT, Navascues J, Casafont I, Val-Bernal JF, Lafarga M, et al. (2006) The PML-nuclear inclusion of human supraoptic neurons: a new compartment with SUMO-1- and ubiquitin-proteasome-associated domains. Neurobiol Dis 21: 181-193.

42. Pinto D, Gregorieff A, Begthel H, Clevers H (2003) Canonical Wnt signals are essential for homeostasis of the intestinal epithelium. Genes Dev 17: 1709-1713.

43. Simmen FA, Xiao R, Velarde MC, Nicholson RD, Bowman MT, et al. (2007) Dysregulation of intestinal crypt cell proliferation and villus cell migration in mice lacking Kruppel-like factor 9. Am J Physiol Gastrointest Liver Physiol 292: G1757-1769.

44. Nieznanski K, Nieznanska H, Skowronek KJ, Osiecka KM, Stepkowski D (2005) Direct interaction between prion protein and tubulin. Biochem Biophys Res Commun 334: 403-411.

45. Dong CF, Shi S, Wang XF, An R, Li P, et al. (2008) The N-terminus of PrP is responsible for interacting with tubulin and fCJD related PrP mutants possess stronger inhibitive effect on microtubule assembly in vitro. Arch Biochem Biophys 470: 83-92.

46. Lechler T, Fuchs E (2007) Desmoplakin: an unexpected regulator of microtubule organization in the epidermis. J Cell Biol 176: 147-154.

47. Holthofer B, Windoffer R, Troyanovsky S, Leube RE (2007) Structure and function of desmosomes. Int Rev Cytol 264: 65-163.

48. Dusek RL, Godsel LM, Green KJ (2007) Discriminating roles of desmosomal cadherins: beyond desmosomal adhesion. J Dermatol Sci 45: 7-21. 